\title{
Pengembangan game edukasi ipa kuartet sebagai media pembelajaran ipa
}

\author{
Nadia Nurmalita, Munzil*, Novida Pratiwi \\ Universitas Negeri Malang, Jl. Semarang No. 5 Malang, Jawa Timur, Indonesia \\ *Penulis korespondensi, Surel: munzil.fmipa@um.ac.id
}

Paper received: 01-04-2021; revised: 15-04-2021; accepted: 30-04-2021

\begin{abstract}
Abstrak
Kurikulum 2013 dalam pembelajaran IPA menuntut proses belajar secara interaktif dan menarik, memberikan ruang yang cukup untuk kemandirian siswa sesuai perkembangan fisik dan psikologis. Pada pelaksanaannya, beberapa siswa kurang tertarik pada mata pelajaran IPA karena sulit memahami materi yang bersifat mikroskopik atau tidak dapat ditangkap oleh indera, bersifat makroskopik atau abstrak, dan sulit termotivasi untuk belajar materi yang bersifat majemuk atau satu materi mencakup banyak sub materi lainnya. Materi yang bersifat majemuk dapat diajarkan dengan metode yang menyenangkan atau metode game edukasi dengan menggunakan media IPA Kuartet. Tujuan penelitian ini adalah menghasilkan media game edukasi IPA Kuartet yang valid dan layak sehingga dapat digunakan untuk belajar secara mandiri dan bernuansa menyenangkan.
\end{abstract}

Model penelitian yang digunakan dalam penelitian dan pengembangan ini diadaptasi dari Plomp yang terdiri dari tiga fase yakni, fase penelitian preliminer, fase pembuatan prototipe, dan fase asessmen. Produk di cetak dalam bentuk kumpulan kartu yang berisi 30 kartu dalam satu set permainan. Produk hasil pengembangan divalidasi oleh ahli media, ahli materi serta guru IPA. Jenis data yang diperoleh bersifat kuantitatif dan kualitatif yaitu berupa angket yang disertai saran dan komentar. Teknis analisis data yang digunakan adalah analisis deskriptif

Berdasarkan validasi media oleh validator diperoleh skor rata-rata 4.66 dengan kriteria sangat layak. Berdasarkan validasi materi oleh validator diperoleh persentase 87 persen sesuai dengan konsep. Validasi kesesuaian pembelajaran dengan kurikulum 2013 oleh validator memperoleh skor rata-rata 4.44 dengan kriteria sangat sesuai

Kata kunci: game edukasi; IPA kuartet; pembelajaran IPA

\section{Pendahuluan}

Pembelajaran IPA pada kurikulum 2013 menuntut pembelajaran yang interaktif dan menarik. Penerapan pembelajaran secara interaktif dan menarik diharapkan mampu mencapai tujuan pembelajaran IPA yang meliputi memahami, mengkaji, dan menggunakan pengetahuan untuk pemahaman konsep dan fenomena dalam pembelajaran sains (Vieira, dkk., 2011; Moran \& Keeley,2015). Realitanya IPA diajarkan sebagai sebuah ilmu yang ditransfer pada siswa agar siswa mampu menghafal konsep, teori dan hukum. Pembelajaran yang bersifat teacher-centered inilah yang mengakibatkan para siswa kurang termotivasi dalam belajar, malas berfikir secara mandiri (pasif) serta dangkal dalam memahami konsep IPA. Hal tersebut dapat mempengaruhi hasil belajar dari para siswa di kelas. Hasil belajar dapat dikatakan sebagai tingkat pemahaman serta pencapaian siswa dalam pembelajaran terhadap indikator pencapaian hasil belajar setelah melaksanakan proses pembelajaran dikelas bersama teman-teman sejawatnya kemudian diukur dengan tes dan instrumen yang relevan (Permendikbud No 53 Tahun 2015). Dari proses yang dilakukan siswa dalam kegiatan pembelajaran, siswa menjadi lebih terampil sebab siswa akan berusaha sendiri memecahkan masalah untuk menemukan konsep yang mereka pelajari. Media pembelajaran juga membantu siswa dalam meningkatkan pemahaman, menyajikan data dengan menarik, terpercaya, memudahkan penafsiran data dan memadatkan informasi (Widyatmoko, 2012). 
Beberapa kriteria yang harus diperhatikan dalam memilih media pembelajaran menurut Munadi (2010) antara lain, karakteristik siswa, merumuskan tujuan pembelajaran, jenis bahan ajar, tersedianya media lain, tipe pemanfaatan media. Kriteria dalam memilih dan menyusun media pembelajaran yakni, sesuai atau tidaknya dengan tujuan pembelajaran yang ingin dicapai; kepraktisan media yang dirancang, terampil atau tidaknya pengajar dalam menggunakan media; adanya pengelompokan sasaran Arsyad (2011)

Clark (1970) dalam Educational for Learning menyatakan bahwa game edukasi adalah alat pengajaran dan pelatihan yang efektif untuk siswa dari segala usia dalam permasalahan peningkatan motivasi belajar dikarenakan game edukasi dapat mengakibatkan komunikasi yang sangat efisien ketika mempelajari konsep atau fakta dari berbagai macam mata pelajaran yang ada di sekolah. Pengalaman belajar atau pengalaman pendidikan yang diberikan kepada para pemain permainan-permainan tersebut dibentuk dengan adanya rangsangan untuk meningkatkan daya pikir, rangsangan perkembangan emosi, sosial dan perkembangan fisik yang mengedukatif para pemain dalam dunia pendidikan dikatakan sebagai game edukasi (Fitria, 2016). Game edukasi di dunia pendidikan telah banyak dikembangkan dengan beragam jenisnya. Game edukasi memiliki dua tipe, yakni tipe penggunaan media TIK (Teknologi Informasi dan Komunikasi) dan media non TIK. Contoh dari tipe penggunaan media TIK yakni berupa PC (Personal Computer) maupun tablet dan juga handphone. Game dengan media TIK sering kali dilakukan secara online (tersambung dengan internet) maupun secara offline (tidak tersambung internet). Media non TIK dapat berupa board game (permainan dengan papan) contohnya monopoli, ular tangga, puzzle, kartu kuartet dan jenis kartu yang lainnya.

Sains Quartet pada penelitian sebelumnya merupakan media non TIK atau merupakan media cetak berupa kartu dengan 14 kategori pada materi sistem organisasi kehidupan yang memiliki nilai intensif sebagai media pembelajaran sebesar $82.85 \%$ mampu meningkatkan hasil belajar siswa, meningkatkan aktivitas belajar, respon siswa dan keterampilan berkomunikasi serta nilai keefektifan sebesar 87.5\% (Fauziah, 2017). Sains Quartet ini memiliki kriteria permainan yang dapat mengedukasi siswa berdasarkan dengan materi yang banyak istilah asing sehingga pengajaran konvensional akan dirasa bosan oleh siswa. Sains Quartet dapat membawa suasana baru dalam mengajarkan materi sistem kehidupan manusia berdasarkan hasil angket yang disebar kepada siswa, sebesar 83\% mengatakan bahwa materi sistem organisasi kehidupan merupakan materi yang sulit untuk dipahami dikarenakan materi tersebut banyak menghafal dan mengandung istilah asing (Fauziah, 2017).

Hasil observasi dengan salah satu guru IPA di SMPN 5 Kota Malang, Kurang optimalnya media yang digunakan menyebabkan siswa masih kesulitan memahami materi. Pengajaran dengan metode ceramah berdasarkan hasil observasi, banyak siswa yang terlihat bosan dengan pengajaran menggunkaan metode konvensional. Dikarenakan untuk memberikan materi lebih dalam dan mudah untuk dipahami siswa, guru dirasa kurang inovasi dalam membelajarkan materi dengan membangkitkan semangat siswa dan respon siswa secara aktif. Berdasarkan uraian di atas, peneliti membuat sebuah pengembangan game edukasi IPA Kuartet sebagai salah satu alternatif pilihan untuk mengajarkan materi menggunakan media baru. Media IPA Kuartet diadopsi dari permainan kartu kuartet pada umumnya dan berkonten pendidikan. Media IPA Kuartet dapat dijadikan sebagai media pembelajaran yang sangat mendukung proses pembelajaran untuk membuat siswa menjadi lebih berminat dan termotivasi dalam mengikuti kegiatan pembelajaran. 
Berdasarkan uraian latar belakang tersebut, peneliti memilih judul "Pengembangan Game Edukasi IPA Kuartet sebagai Media Pembelajaran IPA". Dari permasalahan tersebut maka dapat dirumuskan bagaimana aspek validitas dan kelayakan media IPA Kuartet sebagai media pembelajaran? Maka dalam penelitian ini bertujuan untuk menghasilkan produk berupa media pembelajaran game edukasi IPA Kuartet yang valid dan layak untuk digunakan. Adapun pentingnya penelitian dan pengembangan ini adalah meningkatkan rasa ketertarikan siswa serta meningkatkan pemahaman siswa terhadap pembelajaran IPA, dapat dijadikan sebagai media penunjang untuk mengajar sehingga pembelajaran menjadi lebih inovatif.

\section{Metode}

Penelitian ini merupakan penelitian pengembangan yang akan menghasilkan sebuah produk yaitu IPA Kuartet yang layak dan valid untuk pembelajaran IPA. Model pengembangan yang digunakan diadaptasi dari model pengembangan Plomp (Nieveen, 2010) yang terdiri dari tiga fase yaitu meliputi fase penelitian preliminer, fase pembuatan prototipe, fase asesmen, fase refleksi dan dokumentasi. Instrumen yang digunakan dalam penelitian ini meliputi: instrument validitas media; instrumen validitas materi, instrumen validitas guru IPA. Teknik pengumpulan data diperoleh dari lembar validasi ahli media, lembar validasi ahli materi, lembar validasi guru IPA.

\section{Hasil dan Pembahasan}

\subsection{Deskripsi Hasil Desain Kartu IPA Kuartet}

Desain pertama merupakan kartu kuncian pada tiap kategori materi kartu permainan IPA Kuartet. Kartu kuncian ini di desain untuk menyempurnakan sub kategori kartu yang telah di konstruk oleh siswa kategori yang tepat. Kartu kuncian atau disebut sebagai kartu AS ini, wajib dimiliki oleh siswa yang mengoleksi kartu dalam satu kategori. Keterangan nama kategori kartu pada kartu kuncian hanya terdiri dari satu nama, karena merupakan kartu kuncian. Gambar pada desain kartu kuncian ini, menggambarkan keseluruhan bagian pada satu kategori materi pada permainan IPA Kuartet. Tulisan pada kartu kuncian ini merupakan penjelasan terkait gambar dari kartu kuncian. Maksud dari desain yang dimunculkan ini adalah satu kesatuan kartu yang dapat membuat siswa mengetahui gambar real atau animasi dari bagian organ yang dicantumkan dalam materi IPA Kuartet serta penjelasan yang spesifik mengenai gambar dalam kategori tersebut.

\subsubsection{Hasil dari penelitian pengembangan ini diperoleh dari hasil validasi.}

Desain kedua merupakan desain dari unit sub kategori kartu dalam IPA Kuartet. Pada kartu sub kategori ini memiliki desain empat kotak nama pada bagian atas. Nama-nama tersebut adalah nama sub kategori kartu lain yang harus dikumpulkan apabila siswa mengoleksi pada kategori tertentu. Namanama lain pada unit sub kategori kartu ini, diambil dari bagian-bagian kecil kategori yang disajikan dalam materi IPA Kuartet. Tulisan bercetak merah, menandakan sub kartu yang memiliki nama, gambar dan penjelasan yang saling berkaitan.

Masing-masing dari kategori kartu, memiliki empat judul sub kategori kartu dalam kelompok kartu IPA Kuartet dengan tulisan bercetak merah. Aturan permainan dalam IPA Kuartet ini adalah setiap kelompok kecil siswa 
mengumpulkan empat sub kategori kartu dan satu kategori kartu. Apabila siswa telah mengumpulkan sebanyak lima kartu IPA Kuartet dalam satu kategori yang tepat, maka siswa tersebut dinyatakan menang dan berhak untuk menerangkan kepada teman sejawatnya. Tujuan dari dimunculkannya desain kategori kartu adalah sebagai kunci dari masing-masing sub kategori kartu, sehingga siswa dapat menebak dan mengkonstruk dari sub kategori kartu tersebut masuk kedalam kategori yang tepat. Hal tersebut juga dapat membangkitkan semangat siswa untuk mencari tahu dengan sendirinya bahwa kelompok kartu yang dikoleksinya berada dalam satu kategori yang tepat dan mengetahui kebenaran tentang organ, gangguan, dan sistem urinaria dengan metode bermain.

\subsubsection{Deskripsi Hasil Pedoman Permainan}

Aturan dan pola permainan yang dirancang sebelumnya, yakni setiap siswa dikelompokkan dengan teman sejawatnya berjumlah 2 siswa dalam kelompok kecil. Dua siswa ini nantinya akan dikumpulkan dengan 5 kelompok kecil lainnya sebagai pesaing atau lawan, sehingga dalam satu kotak kartu IPA Kuartet dapat digunakan untuk 10 siswa. Tujuan dari dikelompokkannya siswa dalam jumlah 2 anak ini untuk memberikan kelenggangan kepada siswa agar dapat berdiskusi dalam mengkonstruk konsep materi yang tepat saat mereka bermain dan mengumpulkan kartu-kartu dalam permainan IPA Kuartet. Setiap kelompok kecil nantinya akan mendapat 4 kartu IPA Kuartet secara acak. Dari keempat kartu yang dimiliki siswa saat awal pembagian bersifat rahasia terhadap teman kelompok kecil lainnya dan dari keempat kartu yang dimiliki siswa tersebut, siswa dapat memilah dan memilih kartu mana yang kira-kira mudah untuk mereka kumpulkan dan dirasa memiliki keterkaitan konsep antar kartu dalam satu konsep materi yang tepat. Pada tahap awal permainan ini, siswa secara tidak langsung sudah tertuntut untuk memilih dan mulai mengkonstruk mana kartu yang memiliki kategori yang tepat dan sesuai dengan materi IPA.

\subsection{Hasil Validasi Media}

Hasil validasi media diperoleh dari validator yang merupakan guru IPA bersertifikat media pembelajaran dan memiliki minimal mengajar selama lima tahun.

Tabel 1. Data Hasil Validasi Media oleh Ahli Media

\begin{tabular}{|c|l|c|c|}
\hline No & Kriteria & $\begin{array}{c}\text { Rata- } \\
\text { rata }\end{array}$ & Keterangan \\
\hline 1 & Tampilan Kartu dan Lembar Panduan & 5.00 & Sangat layak \\
& Kejelasan identitas dan judul media pembelajaran & 4.00 & Layak \\
& Daya tarik tampilan meliputi warna kartu & 5.00 & Sangat layak \\
& Daya tarik tampilan meliputi warna & 5.00 & Sangat layak \\
& Kejelasan gambar dan sub kategori materi & 5.00 & Sangat layak \\
& Kejelasan font yang digunakan & 4.00 & Layak \\
& Kejelasan lembar panduan permainan & 4.00 & Layak \\
\hline 2 & Kemudahan kartu untuk dimainkan & & \\
& Materi yang Disajikan & 5.00 & Sangat layak \\
& Kejelasan gambar sub kategori & 5.00 & Sangat layak \\
\hline
\end{tabular}




\begin{tabular}{|l|l|c|c|}
\hline & kartu yang disajikan & & \\
\hline & Skor rata-rata & 4.66 & $\begin{array}{l}\text { Sangat } \\
\text { layak }\end{array}$ \\
\hline
\end{tabular}

Berdasarkan validasi oleh validator ahli media, media IPA Kuartet memiliki nilai rata-rata 4.66 dengan kriteria sangat layak.

\subsection{Hasil Validasi Ahli Materi}

Hasil validasi ahli materi diperoleh dari validator seorang dosen dari Jurusan Biologi Universitas Negeri Malang dan memiliki pengalaman mengajar 10 tahun serta bergelar Master.

Tabel 2. Data Hasil Validasi Kesesuaian Konsep Materi oleh Ahli Materi

\begin{tabular}{|c|c|c|c|}
\hline \multirow{2}{*}{ No } & \multirow{2}{*}{ Konsep } & \multicolumn{2}{|c|}{ Penilaian } \\
\hline & & Ya & Tidak \\
\hline 1 & $\begin{array}{l}\text { Ginjal } \\
\text { Korteks } \\
\text { Medula } \\
\text { Pervis } \\
\text { Nefron }\end{array}$ & $\begin{array}{l}\sqrt{ } \\
\sqrt{ } \\
\sqrt{ } \\
\sqrt{ }\end{array}$ & \\
\hline 2 & $\begin{array}{l}\text { Hati } \\
\text { Enzim arginase } \\
\text { Empedu } \\
\text { Bilirubin } \\
\text { Biliverdin } \\
\end{array}$ & $\begin{array}{l}\sqrt{ } \\
\sqrt{ } \\
\sqrt{ } \\
\sqrt{ }\end{array}$ & \\
\hline 3 & $\begin{array}{l}\text { Paru-Paru } \\
\text { Trakea } \\
\text { Bronkus } \\
\text { Bronkioli } \\
\text { Alveolus }\end{array}$ & $\begin{array}{l}\sqrt{ } \\
\sqrt{ } \\
\sqrt{ } \\
\sqrt{ }\end{array}$ & \\
\hline 4 & $\begin{array}{l}\text { Kulit } \\
\text { Epidermis } \\
\text { Dermis } \\
\text { Kelenjar Keringat } \\
\text { Kelenjar Minyak }\end{array}$ & $\begin{array}{l}\sqrt{ } \\
\sqrt{ } \\
\sqrt{ } \\
\sqrt{ }\end{array}$ & \\
\hline 5 & $\begin{array}{l}\text { Gangguan Organ Ekskresi } \\
\text { Biang Keringat } \\
\text { Hepatitis } \\
\text { Kanker Paru-Paru } \\
\text { Batu Ginjal }\end{array}$ & $\begin{array}{l}\sqrt{ } \\
\sqrt{ } \\
\sqrt{ } \\
\sqrt{ }\end{array}$ & \\
\hline 6 & $\begin{array}{l}\text { Sistem Urinaria } \\
\text { Filtrasi } \\
\text { Reabsorpsi } \\
\text { Augmentasi } \\
\text { Osmo Regulasi }\end{array}$ & $\begin{array}{l}\sqrt{ } \\
\sqrt{ } \\
\sqrt{ } \\
\sqrt{ }\end{array}$ & \\
\hline
\end{tabular}

Berdasarkan hasil validasi validator materi mengenai kesesuaian konsep, memiliki persentase $100 \%$ sesuai.

\subsection{Hasil Validasi Guru IPA}

Hasil validasi guru IPA yakni di validatori oleh seorang guru IPA yang memiliki pengalaman mengajar lebih dari 10 tahun dengan syarat pendidikan minimal Strata Satu. 
Tabel 3. Data Hasil Validasi Kesesuaian Pembelajaran berdasarkan Kurikulum 2013 oleh Guru IPA

\begin{tabular}{|c|c|c|c|}
\hline No & Kriteria & $\begin{array}{l}\text { Skor } \\
\text { Kevalidan }\end{array}$ & Keterangan \\
\hline 1 & $\begin{array}{l}\text { Kesesuaian kategori dengan materi } \\
\text { pembelajaran }\end{array}$ & 4.00 & Sesuai \\
\hline 2 & $\begin{array}{l}\text { Kesesuaian sub kategori dengan materi } \\
\text { pembelajaran }\end{array}$ & 4.00 & Sesuai \\
\hline 3 & $\begin{array}{l}\text { Kejelasan dan kevalidan gambar masing- } \\
\text { masing sub kategori }\end{array}$ & 5.00 & Sangat sesuai \\
\hline 4 & Kejelasan paparan materi pada kartu & 5.00 & Sangat sesuai \\
\hline 5 & $\begin{array}{l}\text { Materi yang disajikan sudah sesuai dengan } \\
\text { Kompetensi Dasar } 3.10 \text { kelas } 8 \text { pada } \\
\text { Kurikulum } 2013\end{array}$ & 5.00 & Sangat sesuai \\
\hline 6 & $\begin{array}{l}\text { Media meningkatkan motivasi siswa dalam } \\
\text { pembelajaran }\end{array}$ & 4.00 & Sesuai \\
\hline 7 & $\begin{array}{l}\text { Media membantu siswa untuk lebih } \\
\text { memahami materi }\end{array}$ & 4.00 & Sesuai \\
\hline 8 & $\begin{array}{l}\text { Kualitas game sudah sesuai dengan tingkatan } \\
\text { siswa SMP kelas } 8\end{array}$ & 5.00 & Sangat sesuai \\
\hline 9 & $\begin{array}{l}\text { Secara keseluruhan materi pada IPA Kuartet } \\
\text { yang dikembanhgkan sudah valid dan layak } \\
\text { digunakan }\end{array}$ & 4.00 & Sesuai \\
\hline & Skor rata-rata & 4.44 & $\begin{array}{l}\text { Sangat } \\
\text { sesuai }\end{array}$ \\
\hline
\end{tabular}

Berdasarkan validasi oleh validator guru IPA, yakni mengatahui kesesuaian materi IPA Kuartet berdasarkan Kurikulum 2013 memiliki nilai rata-rata 4.44 dengan kriteria sangat sesuai.

Tabel 4. Kriteria Validasi dari Tiap Item pada Angket

\begin{tabular}{|l|l|}
\hline \multicolumn{1}{|c|}{ Skor } & Kriteria Validasi \\
\hline $4,2 \leq \mathrm{P} \leq 5,00$ & Sangat valid, sangat layak tidak perlu revisi \\
$3,4 \leq \mathrm{P} \leq 4,1$ & Valid, layak, tidak perlu revisi \\
$2,6 \leq \mathrm{P} \leq 3,3$ & Cukup valid, cukup layak, tidak perlu revisi \\
$1,8 \leq \mathrm{P} \leq 2,5$ & Tidak valid, tidak layak, perlu revisi \\
$1 \leq \mathrm{P} \leq 1,7$ & Sangat tidak valid, sangat tidak layak revisi total \\
\hline & (Arikunto, 2002; 216) \\
\hline
\end{tabular}

Apabila skor yang diperoleh dari validasi yang dilakukan $\geq 2.6$ maka media pembelajaran dinilai cukup valid dan layak sehingga media pembelajaran yang dikembangkan sudah dapat dimanfaatkan sebagai media pembelajaran dalam kegiatan belajar mengajar disekolah. Apabila skor $\leq 2.6$, maka media pembelajaran perlu direvisi. Revisi perlu dilakukan untuk memperbaiki dan menyempurnakan media pembelajaran yang telah dikembangkan

\section{Simpulan}

\subsection{Bentuk Akhir Produk}


Setelah melalui fase validasi oleh validator dan terdapat beberapa masukan saran komentar maka bentuk akhir produk terdiri dari 30 kartu dengan enam kategori Setiap kategori terdapat empat sub kategori kartu dan satu kartu AS, sehingga dalam satu kategori kartu terdapat lima kartu IPA Kuartet.

\subsection{Saran}

Berdasarkan penelitian yag telah dilakukan, beberapa saran yang dapat diambil untuk pengembangan produk lebih lanjut adalah melakukan uji coba penggunaan IPA Kuartet pada kegiatan pembelajaran lainnya yang memiliki karakteristik materi pendefinisian sehingga keefektifan produk yang dikembangkan lebih nampak. Serta saran pemanfaatan produk media IPA Kuartet dapat digunakan dalam proses pembelajaran di kelas maupun secara mandiri.

\section{Daftar Rujukan}

Arikunto, S. (2006). Prosedure Penelitian Suatu Pendekatan Praktik, Rineka Cipta.

Arsyad, A. (2011). Media pembelajaran. Jakarta: PT Rajagrafindo Persada.

Konicek-Moran, R., \& Keeley, P. (2015). Teaching for conceptual understanding in science. Arlington: NSTA Press, National Science Teachers Association.

Munadi, Y. (2010). Media Pembelajaran Sebagai Pendekatan Baru. Jakarta: Gaung Persada Press.

Plomp, T. (2013). Educational design research: An introduction. Educational design research, 11-50.

Vieira, R. M., Tenreiro-Vieira, C., \& Martins, I. P. (2011). Critical thinking: Conceptual clarification and its importance in science education. Science education international, 22(1), 43-54.

Widiyatmoko, A. (2012). Pengembangan perangkat pembelajaran IPA Fisika dengan pendekatan physicsedutainment berbantuan CD pembelajaran interaktif. Journal of Primary Education, 1(1). 